\title{
Influence of Children Government on Learners Discipline Management in Public Primary Schools in Nyandarua County, Kenya
}

\author{
Job Njeru Ngari ${ }^{*}$, Michael W. Gachahi ${ }^{1}$, Maurice K. Kimosop ${ }^{1}$ \\ ${ }^{1}$ Karatina University, KENYA \\ *Corresponding Author: jobngari107@yahoo.com \\ Citation: Ngari, J. N., Gachahi, M. W. and Kimosop, M. K. (2018). Influence of Children Government on \\ Learners Discipline Management in Public Primary Schools in Nyandarua County, Kenya. Pedagogical \\ Research, 3(4), 15. https://doi.org/10.20897/pr/4003
}

Published: December 28, 2018

\begin{abstract}
Discipline management plays a pivotal role in enhancing learners' academic achievement. The Children Government is a key component geared towards enhancing children rights and creating a conducive learning environment. However, the inclusion of children government in discipline management in primary schools has not been appreciated by primary school teachers and administrators. The teachers and school administrators view the learners as too young to engage in discipline management. The purpose of this study was to assess the influence of children government on learners discipline management in public primary schools in Nyandarua County, Kenya. The study adopted the descriptive research design. The study was guided by the Role Theory as advanced by Biddle which argued that human behaviour is guided by expectations held by individuals. The target population was 2517 comprising of 151 deputy head teachers and 1024 teachers, 1338 student government members and four education officials. The study applied Gay principle to arrive at a sample size of 103 teachers, 46 deputy head teachers, 108 student government members and four education officials. Purposive sampling was used to select the education officials. The study employed teachers' questionnaires, deputy head teacher's questionnaire and student government member's interview guide as the primary data collection instruments. An interview guide for education officials was also used. Data analysis involved quantitative and qualitative procedures using Statistical Package for Social Sciences (SPSS, Ver 19) computer programme. Descriptive statistics such as mean and percentages were used to analyse data. The study established that school administrators do not use children government in discipline management of learners. The study concluded that schools lacked capacity to enhance the effectiveness of children government in discipline management in public schools. The study recommends that the school administration should entrust some discipline management to the members of children government in order to improve their relations and enhance effective utilization of the school body. The study provides education stakeholders as well as teachers with strategies for integration of student governance in discipline management in primary schools.
\end{abstract}

Keywords: discipline management, children government, student leadership in primary schools

\section{INTRODUCTION}

The need for educational reforms in Kenya cannot be underestimated from the time when teachers handpicked leaders in educational institutions to current democratic process. Hammond (2011) noted that in Israel, a student leadership which was modeled to promote positive thinking among learners existed in Israel educational institutions. This system was nationally distributed and had a national student council. This system has been successful and has provided a backdrop under which various nations have designed their student organization 
models. Kiprop (2012) argued that involvement of student council members was effective in maintenance of learner discipline compared to corporal punishment. Kiprop further argued that student involvement in decision making changed the student perception towards their environment. He argued that it affected their affective and cognitive faculties and indeed transformed them to better learners.

The children government aims at enhancing learners' discipline. Asiligwa (2015) noted that learners discipline plays a key role in social-political interactions of children which culminate in high academic achievement. Asiligwa argued that children government influences learners' behaviour and boosts learners' academic performance. However, the influence of students' government is determined by several factors including level of training and induction, process of election of members of students' government, level of participation in school administration among others. Therefore, the school administration should ensure that there is an open process for learners to elect their representatives as well as improve the level of engagement of student government in school affairs. Ogol and Thingiru (2016) argued that the era of authoritative leadership in education was impracticable. This was attributed to the democratisation process that the children have undergone from the family unit to the social environment they have been raised in. Thus the concept of participative leadership in education sector cannot be ignored.

\section{THE STUDY OBJECTIVE}

The study objective was to assess the influence of children government in discipline management in public primary schools in Nyandarua County.

\section{Children Government Involvement in Discipline Management in Schools}

Disciplined is the enforcement of organization standards towards achievement of a common organizational goal. Children government plays a key role in management of learners' affair in schools (MoEST, 2015). Vundi et al. (2014) noted that children elected to lead others must undergo some training to assist them perform their roles as a vital link between learners and school administrators. This allows them to have key skills in conflict management, role modeling and peer change agents. As peer agents, the children leaders use various skills key among them role modeling to enhance other learners discipline. They are also used by the school administrators to make the school rules and regulations that learners should adhere to.

According to Mlalazi (2015) when children take part in designing the school rules and regulations, they have a higher propensity to uphold them as they co-own the rules. This enhances discipline management in schools. Mlalazi noted that this is a key aspect of positive discipline management effective in majority of schools. However, Mlalazi argued that care should be taken when incorporating learners to design the school rules, thus avoiding disorder in school administration as learners may develop rules in disregard with core objective of education system. Thus having elected and trained student leaders is a strategy in positive discipline management effective in democratic schools. However, this study was carried out in Zimbabwe where students participated in development of school rules. In the area under the current study, no study has been done to establish learners' involvement in discipline management in primary schools.

Ndung'u and Kwasira (2015) carried out a study on the role of school leaders in enhancing discipline in Nakuru County, Kenya. Using a sample of 100 students, the learners agreed that the student leaders were a force in maintaining school discipline. The learners noted that the members of student council played a key role of demonstrating and instilling a particular desired code of behaviour that was emulated by others, assisted the school administration to handle some discipline cases as well organization of certain school programmes. In as much as this study demonstrated the roles of student government members in discipline management, the study was concentrated in secondary schools which is a different component from the primary school learners who form the subject of this study.

\section{RESEARCH DESIGN}

This study adopted a descriptive research design. Tuckman (2008) defines descriptive research design as a characteristic process which focuses on getting peoples' opinions on a situation as it is. Descriptive survey design lays greater emphasis on sample selection because the major concern is to obtain a broad picture of the social problem prevailing in the defined universe and make recommendations to bring about the desired change. This design was appropriate since the study sought to assess the influence of Children Government on discipline management in primary schools. 


\section{Sample Size and Sampling Procedures}

The sample size represents the proportion of the study population that participates in the study. The study applied the Gay (2003) principle in determining the sample size. Gay indicated that a sample of between 10\% and $30 \%$ of the population is adequate for large and small populations respectively. The study sample was distributed in 46 schools within the two sub counties, 23 from each sub county.

Purposive sampling was used to select deputy head teachers who acted as chief returning officers, two teacher commissioners from every school and three children government members (president, speaker and senator) from the selected schools in the two sub counties. Four education officials were also sampled. The total sample of this study was 261 respondents.

\section{Instruments}

The study employed Deputy head-teacher questionnaires, teachers' questionnaire, children government member interview guide and education officials interview guides as the primary data collection instruments. The instruments were designed in a simple and straight forward language making it easy for the respondent to indicate their response.

\section{Data Analysis}

Data was analysed using both descriptive and inferential statistics with the aid of Statistical Package for Social Science (Version 20.0). Descriptive statistics were used means, percentages and frequency. Generalisations were made from the responses in the interview guide.

\section{RESULTS AND DISCUSSION}

Discipline management in primary schools since the abolishment of corporal punishment has become a source of concern for teachers and school administrators. The schools must develop capacity of learners in school leadership to enhance discipline management among learners. The objective of this study was to find how the schools involved members of children government in learners discipline management in public primary schools in Nyandarua County.

Table 1. Children Government and Discipline Management in Public Primary Schools

\begin{tabular}{|c|c|c|c|c|c|c|}
\hline & \multicolumn{3}{|c|}{ Deputy head teachers } & \multicolumn{3}{|c|}{ Teachers } \\
\hline & $\mathbf{N}$ & Mean & Std. Deviation & $\mathbf{N}$ & Mean & Std. Deviation \\
\hline Children government members counsel other learners? & 46 & 4.6 & 0.9 & 89 & 3.9 & 1.3 \\
\hline Children government members assist in designing school rules? & 46 & 3.8 & 1.3 & 89 & 4.3 & 1.0 \\
\hline $\begin{array}{l}\text { Children government members assist in resolving some disputes } \\
\text { among learners? }\end{array}$ & 46 & 1.5 & 1.6 & 89 & 1.9 & 1.2 \\
\hline $\begin{array}{l}\text { Learners who have been counseled show significant improvement in } \\
\text { positive behaviour change? }\end{array}$ & 46 & 3.3 & 1.5 & 89 & 3.1 & 1.6 \\
\hline $\begin{array}{l}\text { The members of children government are role models to other } \\
\text { learners }\end{array}$ & 46 & 2.2 & 1.3 & 89 & 3.1 & 1.6 \\
\hline
\end{tabular}

Data analysed above shows that deputy head teachers (Mean=4.6). The data shows 4.6 being closer to 5.0 than 2.0 which indicate that the deputy head teachers noted that children government members were not engaged in peer counseling of learners. The same was collaborated by teachers who posted a mean of 3.9 which was closer to 4.0 showing they disagreed with the statement that children government was involved in peer counseling. The children interview also gave collaborative evidence as noted below;

"The school administration and teachers do not refer any learners to us for any counseling. Maybe it is because we are young and in primary school or because we are not trained to peer counsel..." CIG 022.

The sentiments of teachers and deputy head teachers contradict the interview with the education officials who all noted that children government members should play a role in assisting the school maintains learner discipline through counseling among other ways. The findings however note that training should be done to peer counselors for efficiency and effective application of learned skills within educational institutions.

Data also showed that the deputy head teachers $($ Mean $=3.8)$ and teachers (Mean=4.3) shows that the schools do not involve the members of the children government to design the school rules. Where learners through their representatives are involved in making the rules that run an institution, there is more harmony and cohesiveness. The interview with education officials showed that the schools should be more inclusive and include learners' representative to design school rules. Analysis of the responses showed a mean of 1.5 for deputy head teachers. This mean is closer to 2.0 than 4.0 meaning that deputy head teaches agreed with the statement that children government members were involved in discipline management. These observations were collaborated by the 
teachers who posted a mean of 1.9 which was closer to 2.0 than 3.0. This shows that public primary school administrators use the children government as a tool for dispute resolution in primary schools.

\section{CONCLUSIONS}

The schools lacked capacity to enhance the effectiveness of children government application if discipline management in public schools. With a team of equipped children government, the school administration would delegate some of the discipline issues to well-equipped and capable members of children government. Some of the discipline cases to be handled could include peer counseling of learners with general indiscipline such as frequent noise makers in school.

\section{RECOMMENDATIONS}

The study recommends that the school administration should entrust some aspects of learners discipline management to the members of children government in order to improve their relations and enhance effective utilization of the school body.

The Ministry of Education, Science and Technology should ensure the public primary schools have the resources to carry out continuous capacity building to members of the children government. This would enhance its effectiveness in discipline management in schools.

\section{REFERENCES}

Asiligwa, R. A. (2015). Contribution of students' councils to student discipline in public secondary schools in Hamisi Sub-County, Kenya. Unpublished Masters Project, Mount Kenya University; Nairobi.

Gay, L. R. (2003). Educational Research: Competencies for Analysis and Applications (7th ed.). Upper Saddle River, NJ: Merrill Prentice Hall.

Hammond, K. (2011). Universities in Opposition to Israel's Military Occupation and the De-development of the West Bank and Gaza. Cultural and Pedagogical Inquiry, 3(1), 19-32. https://doi.org/10.18733/C35P41

Kiprop, C. J. (2012). Approaches to management of discipline in secondary schools in Kenya. International Journal of Research in Management, 2(3), 120-138.

Mlalazi, L. (2015). Implementation of strategies used to maintain positive discipline in secondary schools in Bulawayo Metropolitan Province, Zimbabwe: Towards a bolistic positive discipline management model. Available at: http://ir.nust.ac.zw/xmlui/handle/123456789/695

MoEST. (2015). Structure of Children Government Assembly. Nairobi, Government Printers.

Ndung'u, E. W. and Kwasira, J. (2015). Contemporary roles of elected Student council on management of public secondary schools in Kenya: A Survey of selected secondary schools in Nakuru East Sub-County. International Journal of Innovative Research and Development, 4(4), 227-232.

Ogol, O. J. and Thinguri, R. T. (2016). A Critical analysis of effectiveness of student council leadership on learners' discipline management in secondary schools in Kenya. International Journal of Applied Research, 3(1), 90-97.

Tuckman, B. W. (2008). Conducting Educational Research, Fourth Edition. New York: Harcourt Brace College Publishers.

Vundi, S. K. Majanga, E. N. and Ondollo, L. O. (2014). Effects of socializing student council leaders on conflict management in secondary schools within Kakamega County, Kenya. International Journal of Education and Research, 2(7), 263-280. 